\title{
Preliminary Hearing Judge
}

\author{
Prof. as. Lirime Çukaj (Papa)
}

University of Tirana, Faculty of Law, Lecture at the Criminal Law Department

Msc. Denisa Laçi

\begin{abstract}
A new figure in the judicial system was foreseen in the legal amendments undertaken in the Code of Criminal Procedure, by law no. 35/2017, in the framework of the Justice Reform. The Code of Criminal Procedure has been changed in various aspects, including in here the changes that are related with the subjects of the criminal proceedings. I have previously set out what are the problems that emerged in the criminal process in general, and in the Preliminary phase of Investigation in particular, to understand the effects of this figure and the reason for it to enter into the judicial system. This preliminary investigation control based in ower law now is made by the Preliminary Hearing Judge (PHJ) and the Preliminary Investigation Judge (PIJ). The main task of this article, is to determine the impact that the PHJ has had on the progress of a fair and complete criminal process, since it has been sanctioned by law and has begun its functions. On the other hand what are the issues that this subject presents regarding the functions that the law attributes and their implementation in practice? The main focus of this paper is precisely those legal provisions that have provided for the manner in which this procedural subject operates, to further understand its impact on the criminal process in general and on the preliminary investigation phase in particular. An important aspect is making an overview of the Italian law from where we are based to foresee this judicial figure. After a comparison between these legal provisions we came in conclusion of the problematics that PHJ presents. We outline, at the end of the study, our conclusions arising from the examination of the preliminary session and PHJ, as well as some recommendations that I consider necessary for the process of criminal proceedings, in the light of the changes that have taken place.
\end{abstract}

Keywords: Preliminary Hearing Judge, Preliminary Hearing, Preliminary Investigation, Decentralized Prosecution, Case Referral to court

\section{Introduction}

Preliminary investigation has been subject to various problems in practice and precisely to avoid such problems and in the context of an effective fight against crime in the country, the legislature deemed it reasonable to undertake legal changes that were mainly related to the Preliminary Investigation phase and the entities that would be prosecuted during this procedural phase. One of the innovations was the introduction of the Preliminary Hearing Judge who would interact at the Preliminary Hearing stage, as an intermediate stage, which had the role of a controller of the files coming from the prosecution and needed judgment.

Undertaking such a change came as a result of the changes that occurred regarding the prosecution, the decentralization of the prosecution. Granting such independence raised the question of who would be the body responsible for exercising control over the activity of the prosecutor? Answering this question and based on previous experience of centralized prosecution, the legislature deemed it necessary to increase control at judicial level, strengthening the powers of the Preliminary Investigation Judge, as well as through the provision of a new judicial figure, that of the PHJ.

The introduction of the PHJ has been accompanied by debate among law scholars but there have been allegations raised at the constitutional level, for which the Constitutional Court has ruled. To understand the relevance of the PHJ it is important to take a brief look at the reasons for undertaking such a reform. The following is a brief retrospective on legal provisions under the Criminal P.C 1995/not amended, on Preliminary Investigation and subjects of this procedural stage. 


\section{Methodology}

In this article we have applied some methods that we considered necessary for studying this judicial figure:

Historical aspects of Preliminary Hearing Judge in the national law over the years

Analitical Methods - analizing the provisions of procedures, highliting the innovations and shortcommings of this judicial figure.

Comparative methodology - We have made a comparison of the provisions with the Italian law, which is the system where we have been based to implement this figure, in way to understand the problems that may have and the solutions for those problems, which we have recommended at the end of the article.

\section{Preliminary investigation and the competent proceeding authority under the Criminal Procedure Code of 1995}

A criminal proceeding goes through several procedural stages, but the most important are three: Preliminary investigation, where the foundations of a criminal proceeding are laid; judgment and execution of decisions. Particular attention of this paper will be the preliminary investigation and the subjects that interact at this stage of the criminal process. This procedural phase had a special arrangement in the Criminal P.C. The prosecution is the prosecution body of this phase which conducts investigations. The body of the prosecution ispresented to us with a particular legal nature, as it has similarities with both the judiciary and the executive. It is also regulated in the Albanian constitution, which means that it is a body of a constitutional level that is not included in any of the powers, but it is considered a sui generis body.

The law provided the prosecution body as a centralized body/sanctioned a vertical hierarchy of the prosecution, with the higher prosecutor exercising control over the lower prosecutor. ${ }^{1}$ As can be observed, such a provision was sanctioned not only legally but also constitutionally. Regarding this hierarchical relationship, the Supreme Court has also ruled, which in the unifying decision no. 04, dated 14.12.2002, stated that: "...Given that the prosecution is a centralized body, in the prosecution offices of the first instance courts, the highest prosecutor is the district prosecutor. The prosecutor of the appeal court a higher prosecutor in relation to that of the district court only when it comes to adjudicating cases..." Meanwhile, in the decision no. 56, dated 29.01.2001, the criminal college of the High Court stated that: "...All decisions taken during the preliminary investigation phase, both dismissal of the case and those referring the case to the court, are decisions taken by the head of the prosecution, regardless of the opinion and attitude of the prosecutor following the case. The highest prosecutor in the case is the district prosecutor or the Prosecutor General. In this sense the highest prosecutor for the district prosecutor's office regarding the reversal of his decisions is the Prosecutor General and not any prosecutor at the General Prosecutor's Office. ..."

Referring to this provision we can understand how the preliminary investigation phase worked and what problems were encountered in practice. The proceeding body during this phase, the prosecution, exercises several functions that fulfill the preliminary investigation phase, namely these functions are sanctioned in the Constitution, Article 148 and in the Criminal P.C., Articles 24 and 25 , which provide that the prosecutor exercises these functions:

Exercise of criminal prosecution also mainly in cases stipulated by law;

\footnotetext{
${ }^{1}$ Article 148 of the Constitution provides that: "The office of the prosecutor exercises criminal prosecution and represents the accusation in court on behalf of the state. The office of the prosecutor also performs other duties set by law. Prosecutors are organized and operate as a centralized body attached to the judicial system In the exercise of their powers, prosecutors are subject to the Constitution and the laws." Law no. 8737, dated 12.2.2001" On the organization and functioning of the prosecution in the Republic of Albania", Article 3 "The Prosecution Office is organized and functions under the direction of the Prosecutor General as a centralized structure, including the Office of the Prosecutor General, the Prosecution Council and the prosecution offices of the judicial system.". and 3/b1. The degree of hierarchy in the prosecution, according to the levels of organization and functioning in the centralized direction, from the highest prosecutor to the lowest prosecutor, is as follows: a) Prosecutors General Prosecutors are higher prosecutors than prosecutors of the prosecution offices at the courts of appeal and prosecution offices the first instance courts; b) the prosecutors of the prosecution offices of the courts of appeal, in the adjudication of appellate cases in their jurisdiction, are prosecutors higher than the prosecutors of the prosecution offices of the first instance courts, which belong to that jurisdiction; c) the prosecutors at the first instance courts, according to their competence, subject and land, are first level prosecutors in the prosecution. 2. Prosecutors, heads of directorates of the General Prosecutor's Office, heads of prosecution offices of the courts of appeal and heads of prosecution offices of the first instance courts, are higher prosecutors than prosecutors in the relevant structures where they exercise their functions..
} 
Conducting investigations and controlling preliminary investigations, delegating powers to the OPGJ (Judicial Police Officer);

Bringing charges in court, and representation on behalf of the state;

The right to decide not to proceed and dismiss the case or charge when the cases are provided for in the law.

Taking measures to execute criminal decisions.

The Prosecution exercises all these powers through assistance from the Judicial Police Officer, who assists the prosecution in its investigative activity.

Realization of investigations in practice presented a number of problems related not only to legal requirements but also to the lack of professionalism in conducting investigations. The legal issues consisted mainly of structuring the prosecution as a centralized body which, as a result, lacked the independence of the prosecution on the case, and consequently neglected the latter to carry out the procedural actions necessary for the case. On the other hand, all decision-making was controlled by the highest prosecutor, who had the power to overturn the prosecution's decisions, which meant that the prosecutor had no decision-making powers on substantive matters. The Code provided that:

The orders and instructions of the higher prosecutor are binding on the lower prosecutor. The higher prosecutor has the right to decide to change or invalidate decisions made by the lower prosecutor on appeal or mainly".1

On the other hand, the professional deficiency was due to the lack of knowledge of the JPO who were the first subjects to come into contact with the crime scene, to take the first investigative actions to obtain evidence, which could later disappear. This was also due to the lack of training for these subjects and this resulted in deficiencies in investigations and incomplete files being sent to the court, which would affect the fair and efficient decision-making of the judicial system. Obtaining evidence was a crucial stage in the process, as this evidence would be available to the court, but as long as the evidence was rejected by the defense because of irregularities in obtaining it, the court found it difficult to deliver justice.

Another consequence was the delay in litigation due to these problems, which would infringe one of the parties' fundamental rights, adjudication within a reasonable time, but at the same time increased the volume of files before judges. There was a high load of criminal proceedings where the offenses under investigation were of minor importance, thus making the prosecutor unable to effectively concentrate qualitatively on the investigation of serious offenses. ${ }^{2}$

With the completion of the investigative phase which normally had an investigative period of 3 months, but for special cases the possibility of extending the Preliminary Investigations deadlines was foreseen, ${ }^{3}$ and proceeded with the second stage of the proceeding which is that of trial.

It is important to consider as one of the factors that influenced the reform undertaking the form of control over the investigative activity of the prosecution. There were two ways in which the control process was implemented, or we can say we have two forms of control, which were:

First, Administrative Control, with this form of control being due to the existence of hierarchical relationships in the prosecution structure and was performed through an appeal to the higher prosecutor. ${ }^{4}$ Second, Judicial control carried out

${ }^{1}$ Criminal Procedure Code of 1995, Article 24/4 and 25/5

2Special Parliamentary Committee on Justice System Reform "Analysis of the Justice System in Albania", 2015.

${ }^{3} \mathrm{lbid}$. Article 324 Deadline extension 1. The prosecutor may extend the period of investigation for up to three months. 2. Further extension, each for a period not exceeding three months, may be made by the prosecutor in cases of complex investigations or of impossibility to complete them within the extended period. The duration of the preliminary investigations cannot exceed two years. Beyond the 2-year period, in exceptional cases, the investigation period may be extended only with the approval of the Prosecutor General for up to one year, for each extension not exceeding three months, without violating the deadline of the length of detention. 3 . The decision to extend the period of investigation is notified to the defendant and the injured party. 4. Investigative actions conducted after the deadline cannot be used

${ }^{4}$ Criminal Procedure Code 1995, Article 24/5 
by the Preliminary Investigation Judge ${ }^{1}$. This form of control was limited as it referred only to complaints about actions that were not committed by the prosecution but needed to be carried out. In practice, there is the possibility of having the decision of the higher prosecutor overturned when the appeal is being reviewed or has been reviewed by the court, due to a lack of clear stipulation in the law. ${ }^{2}$

The court had jurisdiction to hear the appeals of the parties in cases where the prosecutor could dismiss the case, a power which also extended to the criminal offenses of the type of crime, but the law did not clearly specify the court's jurisdiction over the disposition of cases where it found that the decision of the prosecutor was not well founded, and it did not specify the competence of the court to decide on the conduct of investigations and the time limits within which they should be carried out from the moment the acts were returned. The relationship that existed between these two forms of control was that it was directed to the court to exercise control and lose the right of administrative control exercised by the highest prosecutor. On the other hand, if you first exercised administrative control you had the right to later address the court as a higher instance..

Exercising control has been one of the most controversial points in practice and one of the aspects of this control was related to the adequacy of preliminary investigations so that it could be passed through the trial stage. From the analysis of the Code we find that such control was not provided by law, and therefore there was no control filter to determine whether a file/case met the elements sufficient to pass to the trial stage, i.e. could the court, with the elements in the file, to reach a just decision. Such a deficiency in the legislation had consequences that were related to the judgment and the delay of the proceedings. The prosecution, neglecting the investigation and obtaining evidence during this phase, brought about the need to obtain evidence at the trial stage which extended the trial, violated the principle of trial within a reasonable time, but at the same time posed a problem concerning the quality of the charges filed and sent to to be judged.

In response to these problems posed by the law, the legislature deemed it necessary to undertake legal changes, which substantially changed the organizational method and structure of the prosecution body, as a decentralized body, removing the hierarchical dependence that existed with the higher prosecution. The need to balance the functions of the prosecutor and the independence granted was accompanied by the creation of Preliminary Hearing Judge, whose function was to control the activity of the prosecutor during the Preliminary Investigation phase, and to evaluate preliminary investigations. Its functions are expressly enshrined in the legal provisions of the Code of Criminal Procedure, in particular Chapter IX, Articles 332 et seq.

\section{Innovations brought about by the 2016 Reform - Preliminary Hearing Judge}

The initiation of a reform of Procedural Law in general and the preliminary investigation phase in particular came as a response to the problems posed by this phase in criminal proceedings, and more specifically these problems related to:

The way the prosecution was organized as a centralized body/vertical hierarchical relationship, which reduced the responsibility of the prosecution in the process and rendered the latter more negligent in their function, and therefore Preliminary Investigations appeared to have substantial deficiencies in the continuity of the criminal proceedings.

Lack of training of the prosecuting entities of this phase, which resulted in lack of professionalism of these entities in conducting investigations, and consequently the file is incomplete and due to the lack of a supervisory structure on the adequacy of the investigations carried out..

Ensuring a regular legal process and respecting the rights of parties to access the process.

The state of corruption among prosecutors, a phenomenon that has been highlighted by reports not only of organizations interacting in Albania such as the Albanian Helsinki Committee, but also by numerous reports prepared by the European Union.

As a response to these phenomena, it was necessary to strengthen the Preliminary Investigation phase through a number of measures, which focused mainly on preliminary investigation control. The decentralization of the prosecution body and

\footnotetext{
${ }^{1} \mathrm{lbid}$. Article 278 "During preliminary investigations, for cases provided by law, the court decides upon the request of the prosecutor, the defendant, the injured party and private parties. 2. All actions of the prosecutor during the preliminary investigation shall be examined by the same judge"

${ }^{2}$ Special Parliamentary Committee on Justice System Reform "Analysis of the Justice System in Albania", 2015.
} 
the independence it gained based on this prediction brought about the need for intervention and the creation of a competent structure whose relationship with the prosecution would be of a horizontal hierarchical relationship. ${ }^{1}$ In the context that the prosecutor did not depend on the superior prosecutor but would already be controlled by a judicial system structure, there were two ways in which that control would be carried out; first, through strengthening the positions of the Preliminary Hearing Judge, and second, through the sanctioning of the Preliminary Hearing Judge, whose main function is to assess the adequacy of the investigations to take the case judgment.

The Code has exhaustively provided for the functions of this entity, which proceeds at a preliminary hearing as an intermediate stage for the process between investigation and judgment. The main function of this entity is to check the completeness and adequacy of the investigations carried out by the prosecution, to take the case to judgment. Components of this function are considered:

- Verification of the legality of the acts;

- Verifying the usability of evidence,

- Sufficiency of evidence.

The functions and powers that the law attributes to the PHJ in more detail to accomplish its mission consist of:

Examination of prosecutor's request for case referral to the court, within 10 days of submission of the request by the prosecutor, the court sets the date of the hearing. ${ }^{2}$ In the course of this hearing, the court shall notify the parties 10 days prior to the hearing. ${ }^{3}$ The law provides for the obligation to notify in such a case and of the victim or his/her heirs, if their identity and residence are known. In case the defendant has no defense, the court proceeds with the appointment of defense in accordance with the provisions of Article 49 of the Code of Criminal Procedure. The law provides for a legal maximum deadline for the conclusion of the preliminary hearing no longer than 30 days. Such a provision is coherent with Italian Criminal Procedure Code, where our legislation is based on.

It examines the prosecutor's request for dismissal of an indictment or case when proceeding with crimes, and we are faced with one of the conditions provided by law. ${ }^{4}$ During the hearing, the victim is also informed, who has the right to make his/her own claims about the case. After considering all the evidence of the prosecutor, the court decides whether to accept the prosecutor's request or return the acts to the prosecutor to continue the investigation or formulate the request for transfer to court. In this case the parties have the same rights of appeal as in the case when the prosecutor himself has decided to dismiss the case in the case of an offense. ${ }^{5}$ The defendant may appeal only the most favorable fact of dismissal of the charge or case.

It examines the appeal against the prosecutor's decision to dismiss the charge or the case for criminal offenses. ${ }^{6}$ After making such a decision, the prosecutor is obliged to notify the parties, the defendant and the victim. The appeal is examined by the court in the consultation chamber within 15 days of receipt of the acts. The review of the appeal is conducted in the presence of the parties, the defendant, the prosecutor and the victim or heirs when his/her place of residence is identified and known. At the conclusion of this decision the court may decide:

Leave the decision of dismissal in force, when it considers that we are facing cases sanctioned in article 328/1 of the Code of Criminal Procedure. Appeal to this decision may be made by the defendant and the victim to the court of appeal and the latter when receiving the victim's appeal returns the acts to the prosecutor to proceed with the investigation or the request to refer the case to the court. When it accepts the appeal of the defendant, it decides to dismiss the case for a more favorable cause.

\footnotetext{
${ }^{1}$ Constitution of the Republic of Albania, as amended 2016, Article 148.

${ }^{2}$ Criminal Procedure Code, as amended by Law no. 35/2017, Article 332

3 Italian Criminal Procedure Code, Article 418. After the submission of the request until the hearing, no longer than 30 days should be allowed under the Italian Code, unlike our law with no longer than 10 days, a period which in our opinion is too short, thus bringing a problem with notifying the parties.

${ }^{4}$ lbid., Article 329/a

5 lbid., Article 329/b

${ }^{6}$ lbid., Article 329
} 
It returns the acts of the prosecutor for the continuation of investigations when they indicate that they are incomplete, specifying the directions for their concetration and, where appropriate, the actions to be carried out, and specifying the time limit within which investigations should be completed;

It returns acts to the prosecutor ordering to formulate an indictment and submit a request for adjudication of the case, when it considers that the investigation is complete and that there is sufficient evidence to support the indictment. Such a legal provision has been the subject of opposition by the Order of Prosecutors of the Republic of Albania (OPRA) to the Constitutional Court, as a legal sanction which contravenes Article 148 of the Constitution, where it is sanctioned that prosecution is the exclusive competence of the prosecution and the constitution does not provide for any case where this power may be restricted. Granting such an attribute to the court leads to taking the prosecutor's powers, going beyond the controlling boundaries that the law provides for the PHJ, argued OPRA representatives. Concerning the prosecutor's powers to prosecute, the $\mathrm{CC}$ has stated in a number of its decisions, but in the case under review it rejected the request as unfounded by law. ${ }^{1}$ We consider this decision of the $\mathrm{CC}$ as incorrect interpretation of the law resulting in the creation of the phenomenon of compulsory prosecution, which denies the prosecutor the right to assess the opportunity to pursue the prosecution in the specific case and consequently, a violation of his/her powers.

Granting such powers to the court violates the rights of the defendant whose position is aggravated by the fact that the law denies the right to appeal such a decision. The defendant has the right to complain equally as a victim only when he/she has the dismissal decision in force to request a more favorable cause of dismissal. In the other two cases the court recognizes the right of appeal only to the prosecutor. ${ }^{2}$ In the case when the prosecutor is required to formulate the indictment, the defendant is denied the right to appeal but we consider such a provision to be unjust, as granting the right of appeal only to the prosecution is considered ineffective, based also on the decentralization of the prosecution, where the appeal filed by the prosecutor to the Appeal will be prosecuted by the prosecutor acting at the Court of Appeal and consequently the latter may waive the appeal and thus the appeal remains ineffective in guaranteeing the rights of the defendant.

It examines requests for revocation of a decision to dismiss an indictment or case at the request of the prosecutor, the victim or his/her heirs when new data or evidence emerges or is disclosed, indicating that the decision is not grounded. When making such a request, the victim shall submit and file together with the request the new evidence or facts proving the situation. The request is examined in the consultation room. When deciding to accept the request, the court revokes the dismissal decision and returns the acts to the prosecutor, who resumes the investigation. ${ }^{3}$ But if the court decides to reject the claim, the victim has the right to appeal to the court of appeal against this decision. It is worth interpreting to whom the legislature refers to the concept of new evidence in this case. In our opinion, new evidence will be evidence that was not known at the time of the investigation and is newly revealed or reported, so we will be in the same situation when seeking a review of the verdict due to the emergence of new evidence, and not evidence which was known but due to negligence was not obtained by the competent authorities.

Examination of the appeal of the victim or the person who has filed a charge on the prosecutor's decision to suspend the investigation. The appeal is examined in a consultation room within 30 days. No appeal is allowed against the decision. When the appeal is upheld, the court decides to resume the investigation. ${ }^{4}$ In this way the court does not allow the prosecutor to abuse his powers and allows the victim to seek further investigation, thereby protecting the victim's interests, as in the case where the latter complains about the prosecutor's failure to initiate proceedings.

It examines the requests of the parties regarding the invalidity of the acts or the uselessness of the evidence and where appropriate may order their repetition. The parties, at the beginning of the preliminary hearing, put forward their allegations concerning the investigation. The prosecutor first makes his statements, then the defendant, who may challenge the prosecutor's acts or demand the uselessness of certain evidence which has not been obtained according to legal requirements. The victim has the same right to ascertain whether the acts are invalid and that he/she may file a claim,

\footnotetext{
${ }^{1}$ www.gjykataelartë.gov.al Unifying decision no. 02 dated 20.06.2013; www.gjykatakushtetuese.gov.al decision no. 14, dated 21.07.2018, "The power of the prosecutor to ignore or dismiss a criminal case, as an aspect of its constitutional functioning of the prosecution, is in accordance with the rule of law".

2 Criminal Procedure Code, as amended by law 35/2107, Article 329/6

${ }^{3}$ Criminal Procedure Code, as amended by law 35/210, Article 329/c

${ }^{4}$ Criminal Procedure Code, as amended by law 35/2017, Article 326
} 
either himself/herself or through the legal representative, with regard to the invalidity of the acts, or the usability of the evidence. The victim may also exercise this right in cases where the defendant files a motion for summary judgment and in this case it may be a reason for the court not to accept the summary judgment for the defendant.

It expresses about the parties' allegations regarding the charge or legal qualification of the criminal fact. Both the victim and the defendant in this case have the right, through the representative, to submit their opinion on the accusation raised by the prosecutor or the legal qualification of the offense and, where appropriate, the court, when finding that the prosecutor has erred in these two respects, requests the latter to make the appropriate adjustments. At the same time, it informs the head of the prosecution office in case the prosecutor does not obey the requests of the PHJ. ${ }^{1}$ Accurate determination of the criminal fact is a decisive condition on the validity of the decision of the PHJ, ${ }^{2}$ but this does not imply that it is the PHJ that determines the criminal fact for which the defendant is being prosecuted, as this is the exclusive competence of the prosecutor. The right to dispose of the indictment is a key component of the prosecution's exercise of jurisdiction, which continues to be exercised at the trial, as it does not end with the conclusion of preliminary investigations. The reason for establishing this institute is to enable the prosecutor to reflect based on the available acts on the criminal fact and the accusation raised so that the file is as complete as possible.

Implementing such a provision in the code is very helpful in case law, at a time when the prosecutor is twice given the opportunity to dispose of new charges, once in the preliminary hearing and once in the judgment. This is undoubtedly considered with regard to guaranteeing a fair legal process, in terms of procedural justice. ${ }^{3}$

The Criminal Procedure Code has clearly sanctioned the cases in which a change of charge may be made, which is the same as the chapter of new charges in the criminal process sanctioned in Articles 372 et seq. of the code. ${ }^{4} \mathrm{~A}$ problematic situation of this institute appears in the case of changing the legal qualification of the criminal fact following the guidance of the $\mathrm{PHJ}$, if the prosecutor fails to comply with the PHJ instruction, he may, by reasoned decision, return the acts for the continuation of the investigations, which brings regress in the case. ${ }^{5}$

The Preliminary Hearing Judge, when the parties claim and when he or she deems it reasonable and generally orders the necessary investigative actions to be taken on the case, in the context of conducting thorough investigations. In this case it may also specify the direction of the investigation and the time limit within which it should complete the investigation. ${ }^{6}$

By analyzing the code in its entirety, the PHJ may also be attributed certain functions, which include, in addition to receiving the requests of the parties, such as those for summary judgment and the provision of evidence under Article 318 of the

\footnotetext{
${ }^{1}$ Criminal Procedure Code, as amended by law no. 35/2017, Article 332/d

${ }^{2}$ Criminal Procedure Code, as amended by law no.35/2017, Article 332/e paragraph 2 "2. The decision is invalid when the defendant is not accurately identified, or when the requirements provided for in point (c), paragraph 1, of this article are missing or insufficient. The decision to refer the case to the court shall contain: $c$ ) the presentation of the criminal fact and its circumstances, indicating the relevant provisions of the law"

${ }^{3} \mathrm{~A}$. Belishta "Defendant's procedural safeguards in a criminal proceeding, through the application of a set of provisions on changing charges, seen from a historical perspective and strengthening them with amended procedural provisions", Criminal Law Department International Scientific Conference "criminal law between Tradition and Challenges of Actuality" pg. 456

${ }^{4}$ Criminal Procedure Code, as amended by law no. 35/2017 Article 332/d"1. When during the preliminary hearing the fact is different from that described in the request to refer the case to court, another criminal offense emerges, pursuant to letter "b" of paragraph 1 of Article 79 , or an aggravating circumstance not mentioned emerges, the prosecutor changes the charge and communicates to the present defendant. When the defendant is not present, the new indictment is communicated to his lawyer, who is given no more than 10 days to communicate with the defendant.

2. When during the preliminary hearing a new criminal fact emerges about the defendant, which is not mentioned in the request to refer the case to court and for which it should be proceeded mainly, the court allows the communication of the charge for the new fact, when the prosecutor submits a request and the defendant consents. Otherwise, the court returns the prosecutor acts related to the new charge and notifies the chief prosecutor.

3. When during the preliminary hearing it turns out that the legal statement of fact is incorrect, or when the charge is not clearly and correctly worded, the court invites the prosecutor to make the necessary corrections. If the prosecutor does not act, the court decides to return the acts. This decision is notified to the chief prosecutor.

${ }^{5}$ This case would be problematic and because after the investigation it is the same judge who returned the acts who will consider the second request of the prosecutor, in case the prosecutor did not follow the instructions of the PHJ, it would bring the process into a stalemate, a "silent conflict between the parties".
}

${ }^{6}$ Criminal Procedure Code, as amended by law no. 35/2017, Article 332/ç 
Code of Criminal Procedure, and powers regarding the assignment of medical measures. The Code in Article 46 provides that when it is found that the mental state of the defendant is such that it needs to be cured, the court, mainly, orders him to be admitted to a psychiatric hospital. Although the code does not explicitly state which court is competent to deal with such a decision, we are of the opinion that since mental incapacity may arise at any point in the proceedings, that court operating at that stage should be competent. Such a conclusion is also reached by the fact that in paragraph 3 of this provision it is provided that when incapacity appears to us during the Preliminary Investigation, the prosecutor asks the Court to authorize the hospitalization of the defendant to a psychiatric hospital. This paragraph in conjunction with Article 278 where the competence of the PHJ is provided, it results that during this phase the PHJ who is competent for the Investigation phase decides. The same logic should be followed if the incapacity is shown to us during the Preliminary Hearing, with the power to decide lying with the PHJ.

By analyzing the functions and powers of this figure, we can come to some conclusions about the advantages and disadvantages of the $\mathrm{PHJ}$ :

Firstly, it gives you the opportunity to challenge the evidence obtained in the investigation by seeking the uselessness or invalidity of the act.

Secondly, it provides the defendant with the opportunity to exercise effective defense, since at this stage you can examine the evidence of the preliminary investigation, without going through the judgment. It thus guarantees the time needed to set up a defense strategy.

Thirdly, access to evidence orientates the credibility of the charge but at the same time directs the search for the application of special judgment when it finds that the evidence is strong and seeks in this case the benefits that special judgments can bring.

Fourth, it obliges the prosecution to identify its weaknesses and directs it to the necessary investigative actions it needs for the process. This way it guarantees thorough investigations.

Fifth, the recording of the hearing may serve as evidence judgment phase.

Finally, the subject of a judicial dispute may reveal little about the defense strategy and orient the charge on how it should act in this case.

We can say that in many cases what constitutes an advantage for one party is a disadvantage for the other. But no one can deny that at present the legal framework has made an effective adjustment having regard to the parties' relation to guarantee the most effective means of dealing with them.

The PHJ performs its competences through a certain standard of proof. The standard of proof is the level of evidence required in a legal action to convince the court that a particular allegation is true. ${ }^{1}$ Three types of standards apply to a criminal proceeding throughout its development; the standard of reasonable doubt that the court applies in determining the precautionary measures; The standard of judgment beyond any reasonable doubt, when the court has the guilt of the defendant; and the standard of proof adequacy that the PHJ applies. ${ }^{2}$ The latter through this standard disposes of passing the case for judgment or not, based on the totality of evidence available until the preliminary hearing. It assesses whether the court of appeals based on this evidence is able to reach a verdict on the guilt or not of the defendant, if he/she then refers the case for trial, otherwise he/she may return the acts to the prosecutor and request for the conduct of further investigation.

Of particular importance in dealing with the competences of this subject is the relationship that this subject has with some special adjudications, namely judgment in absentia and summary judgment.

The judgment in absentia is an institute which was provided in Criminal Procedure Code with the legal changes undertaken. The anticipation of such a trial came as a result of the issues arising in practice where the defendant was tried without knowledge of the criminal proceedings against him/her. In this way he/she was denied the right to effective defense.

${ }^{1}$ OSCE "Analysis of the Criminal Justice System in Albania, Report on the Development of a Fair Trial Program ", 2006

${ }^{2}$ Criminal Procedure Code, as amended by Law no. 35/2017 Articles 228, 4/2 
An effective means of appeal was not guaranteed for this category of persons so that it could challenge the decision taken in absentia, a problem for which Albania has often been subject to ECHR decision-making. ${ }^{1}$

In the context of our work, a problem that may arise in practice relates to the judgment in absentia of the defendant and the request for review. Is the defendant entitled to seek summary judgment and where to file it? When the accused person is not present (in absentia), the court proceeds with the adjournment of the trial for one year in order to carry out the relevant search actions of the person. This procedural remedy provided the defendant with a guarantee that if he/she would appear within this time limit, he/she could benefit from the summary judgment. But even in this case if, despite the searches, the person is not found and fails to know about the process, the court proceeds with the revocation of the suspension decision and refers the case to trial, ${ }^{2}$ consequently the absent defendant was again denied the opportunity to benefit from the summary judgment.

In the case of a defendant in absentia, it is presumed that the Preliminary Hearing phase has been exhausted and consequently when the defendant appears and requests a review, for one of the reasons set forth in the Code, ${ }^{3}$ we no longer have a preliminary hearing. Such an arrangement denies the right of the sentenced in absentia to benefit from the summary judgment, as long as this case is not included in the cases provided for in Article 403/1 for the submission of the request at the hearing.

A person tried in absentia has been denied the right to an effective defense as long as he/she was unaware of the criminal proceedings against him/her. And the request for review is provided as a necessary tool to guarantee individuals' rights to due process. Once a request for a review is received and the case is returned for retrial, only an obligation for the retrial court arises and it is to restore the defendant to the same situation it would have been if it had been duly notified of the proceedings against him.

In such cases, the court shall guarantee to the defendant all the rights he enjoys under the legal acts which are part of the legal order of the Republic of Albania, without limiting any right, including the right to seek summary judgment. Otherwise the appeal remedy, the request for review would not be considered an effective remedy, this being referred to the jurisprudence of the $\mathrm{CC},{ }^{4}$ which is in line with the ECHR's decision-making. The latter has stated in relation to Albania that:

...The refusal to resume proceedings in the absence of the defendant, without indicating that the defendant waived his right to be present at the trial, was found to be a "flagrant denial of justice", making the proceedings "openly in contravention of the provisions of Article 6 or the principles expressed therein" ... 70. The Court reiterated its findings in other decisions too that when a complainant was convicted in violation of his rights guaranteed by Article 6 of the ECHR, the most appropriate form of redress would be to make the complainant, as much as possible, be placed in the position that would have been had this provision been respected."(see Izet Haxhia against Albania).

Although the practice is oriented towards accepting summary judgment requests, in the case of trials in absentia, we are of the opinion that appropriate intervention should be made to establish the judgment in absentia, as one of the cases of Article 403/1, where the summary judgment request may be presented at a court hearing and not a preliminary hearing. Such a provision would avoid any possible future abuse by the authorities of the defendant's right to a summary judgment. Another way is to apply the judgment in absentia in the same way as in the Italian system, where the suspension is made at the preliminary hearing stage and resumes only in the cases provided by law. ${ }^{5}$

\footnotetext{
${ }^{1} \mathrm{https}: / /$ www.echr.coe.int, see Shkalla against Albania; Caka against Albania; Izet Haxhia against Albania.

2 Criminal Procedure Code, as amended by Law no. 35/2017, Article 352/1

${ }^{3}$ Criminal Procedure Code, as amended by Law no. 35/2017, Article 450, see Article 352/ judgment in absentia.

${ }^{4}$ www.gjykatakushtetuese.gov.al Decision no. 64, dated 16.10.2017 stating: "The Court, referring to the jurisprudence of the European Court of Human Rights of the ECHR with regard to the interpretation of Article 13 of the ECHR, which clarifies the content of the term "effective complaint", has stated that it is important to determine that a range of remedies, by case, are available to the individual and if they provide him with real opportunities to settle disagreements effectively. In this regard, it has been identified that one of the criteria that must be met in order for an appeal to be effective is that the remedy provides clear and secure opportunities for reinstatement of the infringed right"

5Italian Criminal Procedure Code, Article 420 bis, 420 quarter, Article 420/2 quinquies, provides that "the PHJ will revoke the order of trial suspension: if the accused is found after searches; if in the meantime the defendant has appointed a lawyer; in any other case where it is certain that the accused is aware of the proceedings against him; if a judgment act is to be submitted in accordance with Article 129/being in the condition of granting a cessation order".
} 
The introduction of the preliminary hearing as an intermediate stage, as an example of the Italian system, has been considered an important element for the system as it improves quality and completeness of adjudication in criminal proceedings. But is it necessary to apply this stage in any circumstance?

In order to understand the answer to this question we must remember once again the main purpose and function of the $\mathrm{PHJ}$, which is to check the adequacy and completeness of the preliminary investigations. In cases when it is not necessary to carry out this control, there are also cases when the preliminary hearing can be avoided:

- Direct judgments. The Code has clearly sanctioned the conditions under which direct prosecution may be sought by the prosecutor. ${ }^{1}$ At the heart of a direct trial is the basic condition for a preliminary investigation to be complete, which means that there is no need for further investigation. Since this form of adjudication completely eliminates the preliminary investigation, it results that the PHJ is not involved at all as part of the process and the case goes directly to judgment.

- Case of the prosecutor's decision to dismiss the criminal case, when proceeding for criminal contravention. One of the powers of the prosecutor is to decide the dismissal of a case where it constitutes criminal contravention. ${ }^{2}$ In this situation we do not address the PHJ at all, except when the victim or the defendant addresses him with an appeal against the prosecutor's decision.

What comes up for discussion is what happens when the court accepts the victim's complaint and returns the acts to the prosecutor and orders the prosecutor to formulate the request to bring the case to trial. Could the same judge then adjudicate the prosecutor's request to have the case brought to court, and would we have incompatibility of functions? In our opinion, we are not in a state of incompatibility, as the PHJ, as we said, does not make a thorough verification of preliminary investigations. As a result, from the interpretation of the provision it turns out that it is the same PHJ who will also consider the request for the case to be referred to court.

= Filing of application for approval of Criminal $\mathrm{Order}^{3}$. In cases where the prosecutor proceeds with criminal offenses and considers that it is not necessary to apply the prison sentence, he asks the court to approve the criminal order, which determines the sentence that is applied to the defendant, with a fine as the main punishment. During this special adjudication the PHJ does not interfere and the order is approved by the Judge of judgment. Against his decision, the appeal is re-filed with this court and, if this appeal is accepted, proceeds to ordinary trial. The provision is made in such a way that when a criminal order is approved, the court examines issues of judgment such as the proportionality of the sentence, elements which fall outside the jurisdiction of the PHJ.

The legislation has only sanctioned 3 cases in which we may have avoidance of the preliminary hearing, but in our opinion this should have been applied to other cases too. Taking the type of criminal offense as a criterion, which does not represent a complexity in the conduct of investigations, they do not therefore need to be examined by a judicial authority. It should be emphasized that one of the aims of the sanctioning of the PHJ has been to avoid delay in processes and if we apply this institute in any criminal proceeding, we would lose one of the purposes for which this judicial instance was sanctioned.

\section{CONCLUSIONS}

The undertaking of legal reforms in recent years, having as reference/guidance the Italian legal system, brought about a number of changes in the organization and functioning of legal structures operating at each stage of criminal proceedings. As part of the implementation of the separation and balancing of powers, the manner of the organization of the prosecution was completely transformed, which has led to an increase in the efficiency of the prosecution and consequently an increase in the fight against crime.

The new legal framework serves to apply the rights of the parties to the process and has opened a new path for criminal proceedings. Granting control powers to the prosecution activity by raising it to a judicial level in a horizontal relationship between the two structures will avoid the various abuses that have so far occurred in practice and bring about more effective justice.

\footnotetext{
${ }^{1}$ Criminal Procedure Code, as amended by Law no. 35/2017, Article 400

2 lbid., Article 328

${ }^{3}$ Criminal Procedure Code, as amended by Law no. 35/2017, Article 406/a
} 
We can say the PHJ has brought a number of positive developments to the process, reducing the duration of an adjudication by submitting as thorough a case as possible to adjudicate.

Despite the positive aspects of this figure, it should not be forgotten that the legislator in a series of steps, attempting not to copy paste the Italian legislation, has caused a number of problems which may affect the rights of parties to the process. A typical example is the case of adjudication in absentia and the defendant's right to benefit from special adjudication. These claims only appear at a preliminary hearing, but while the person is tried in absentia, he/she loses such a right, thereby denying him/her the right of access to court and trial in due process. This problem should not have an immediate solution so long as we have neither the Supreme Court, to unify the practice of interpreting the provisions, nor the Constitutional Court, to express on the constitutionality of these provisions.

The PHJ has a range of powers ranging from expressing a cessation of a case in cases of crimes when the prosecutor requests it or when finding that we are in a cessation condition sanctioned by Article 328 of the Code of Criminal Procedure. The introduction of such an intermediate phase has brought about a new legal framework, in view of improving criminal proceedings.

It turns out that the functions of the PHJ are set out in all the legal provisions of the Code of Criminal Procedure. As a consequence, we need to be careful when analyzing and studying them in practice. The establishment of this judicial figure serves the realization of judicial control over the Preliminary Investigation phase, in addition to that carried out by the PIJ (Preliminary Investigation Judge). It has consequently brought about more thorough investigations and more effective justice, where the parties have a range of remedies to seek their rights, and to avoid abuse by state authorities.

\section{RECOMMENDATIONS}

At the end of this paper we consider it necessary to make some recommendations regarding the $\mathrm{PHJ}$ and this stage of the criminal proceeding, including its method of operation.

It is important that in its judicial activity the $\mathrm{PHJ}$ is concise in applying the relevant legal provisions and making decisions applying the standard of adjudication, which is that of sufficiency to adjudicate. It is important to consider all the claims of the parties at this stage of the proceedings by referring to law and evidence.

From the analysis of the provisions we are of the opinion that the legislature should proceed with the relevant changes regarding the judgment in absentia, and include it in one of the cases where the requests for special trial should be foreseen at the preliminary hearing stage. Such an adjustment is necessary as long as both the SC and CC are unable to comment on the case because of the current impasse.

In our opinion, the power of the $\mathrm{PHJ}$ to return the acts to the prosecutor and to request the formulation of the indictment is in contravention of the constitution, and the $\mathrm{CC}$ in its decision-making should have expressed by decision on this as it infringes the prosecutor's exclusive competence to carry out the criminal prosecution.

The legislature must be coherent in their legal provisions and undertake legal changes related to Article 334 of the Code of Criminal Procedure, "request for summary trial", in order to comply with the new sanctioned provisions. It should avoid the abuses and discretion of the courts in assessing cases by avoiding the contradiction between the legal provisions.

Concerning the right of appeal in the case of dismissal of the case by the prosecutor or the PHJ, we consider that the legislature has not made an accurate provision of this right to guarantee the access of the defendant and the victim to the process. The right of appeal of the defendant is not always exercised, and moreover this right is related to the status of the defendant, which limits the right of appeal of the person under investigation in those cases where the dismissal of the case is decided by prosecutor. In such a situation the person against whom proceedings have been instituted does not necessarily have the status of a defendant. We consider such a provision to be in contradiction with the unifying decision no.2/2013 which provides for the status of the person being prosecuted and the rights he/she enjoys under this status.

On the other hand, in the case of the disposition of the PHJ to return indictments and request to formulate indictments, the law provides for the right of appeal only to the prosecutor and not to the defendant, with such a provision being ineffective as long as the prosecutor is already decentralized and after making an appeal the case is pursued by the Appellate Prosecutor who may waive the appeal and therefore remains ineffective, with the PHJ's decision being in force. In order to remedy this situation the law must also recognize the right of appeal to the defendant in such cases. 
The same problem also applies to the victim, who has the right to complain, but may lose that right as long as his/her notification is limited by the legislature to the fact of identifying the victim. In the event that the victim is not identified, the proceeding authority is not obliged to notify, leading to the violation of equality before the law for the parties and denial of access to court. We recommend appropriate interventions to address legal deficiencies that will in practice result in a violation of the rights of parties in the process.

Biblography

[1] Belishta "Defendant's procedural safeguards in criminal proceedings, through the application of a set of provisions on changing the charges, viewed from a historical perspective and strengthening them with the amended procedural provisions", Criminal Law Department International Scientific Conference "criminal law between Tradition and Challenges of Actuality

[2] Constitution of the Republic of Albania 1995

[3] Constitution of the Republic of Albania, as amended 2016

[4] Criminal Procedure Code 1995

[5] Criminal Procedure Code, as amended by law no. 35/2017

[6] Italian Criminal Procedure Code

[7] OSCE Analysis of the Criminal Justice System in Albania, Report by the Fair Trial Development Project, 2006

[8] Special Parliamentary Committee on Justice System Reform "Analysis of the Justice System in Albania", 2015

[9] Vasilika Hysi "Report on amendments to the Criminal Procedure Code"

[10] www.gjykatakushtetuese.gov.al

[11] www.gjykataelartë.gov.al

[12] https://www.echr.coe.int 